\title{
Univariate Degradation of Indigo Carmine in Aqueous Solution by Inactivated Biomass in Heterobasidion Insulare: Preliminary Studies
}

\author{
Yue Li-Hong', Wang Yu-Jun ${ }^{1}$, Li Lan², Zhang Yue-Hua** \\ ${ }^{1}$ Institute of Applied Microbiology, Jiamusi University, Jiamusi, Heilongiiang Province, China, 154007 \\ ${ }^{2}$ College of Science, Jiamusi University, Jiamusi, Heilongjiang Province, China, 154007
}

Received: 2 February 2016

Accepted: 14 May 2016

\begin{abstract}
The role of white rot fungus in the treatment of dye wastewater has been widely researched. Numerous genera of fungi have assumed responsibility for dye decolorization, either in living or dead form. This study looks at the degradation of an acidic dye, indigo carmine (IC), as the medium in an aqueous solution by means of biological degradation in dead fungus of Heterobasidion Insulare. The dye decomposition of reaction time relies on the primary dye concentration, mortality quantity of biomass, churn rate, and primary $\mathrm{pH}$. Experimental results show that an increase in the mortality quantity of biomass significantly affects dye degradation. The highest degradation rate of dye was achieved at 125-150 rpm. Slightly reduced biological activity was found when we reduced the stirring rates. The $\mathrm{pH}$ of the reaction system is a slight variation in the 4-8 range, when dye degradation efficiency was not affected so obviously. The dye of color discoloration was observed to occur rapidly within 60 minutes. The degradation of dye by inactivated biomass of $H$. Insulare definitely depended on original dye-wastewater concentration in the aqueous solution. Dye degradation was reduced from $64 \%$ to $93 \%$ as the original contents were enhanced from 50 to $500 \mathrm{mg} / \mathrm{l}$. This study was desirable in that it shows it is possible to degrade textile dyes by inactivated biomass of H. Insulare.
\end{abstract}

Keywords: indigo carmine, decolorization, Heterobasidion Insulare, inactivated biomass

\section{Introduction}

Textile industries generate huge volumes of wastewater that contain large amounts of dye. The removal of dye from textile effluents is one of the most significant

*e-mail: zhangyaohua_2008@163.com environmental problems in that dye wastewater is highly visible and undesirable and also reduces light penetration and photosynthesis [1]. Due to the stable chemical structure of the dye molecule, in conventional conditions dyes in chemical synthetic have stable three-dimensional space molecules and are resistant to the decomposition of biological enzymes. At present, it has numerous means of eliminating dyes, such as membrane-separating 
technology, biological treatments, chemical flocculation, electrochemical oxidation, physical coagulation, ionic reverse osmosis, ozone oxidation, and physical adsorption [2-3].

Degradation of wastewater in a routine treatment process in biological methods is not a perfect method. It is unacceptable to use traditional methods of biological degradation of dye wastewater due of the low biodegradability of dye wastewater in cost and efficiency [4]. The method of using activated carbon as an absorbent to absorb the dye wastewater is exciting. However, it is prohibitively expensive and has low adsorption capacities activated in carbon [5]. Therefore, it is necessary to explore new technologies and new processes and efficient for degrading dye wastewater. Bio-sorption can be a defined organism, an organism's province metabolites, and debris on the grounds in which to absorb the organism derivatives, metal closure, and dyes causing odor [6-7]. In the current study focuses on the active microbial cell degradation capacity of the dye. However, few studies have focused on the dried fungal biomass degradation of dye wastewater. Both living bio-mass and dead fungi biomass already have proven to be able to remove dyes due to the existence of various functional isozymes groups on the total biomass of organisms [8-9]. However, it has been proven that inactivate bio-mass cells may offer more merit than active cells. First of all, the active biomass process of microbial degradation of dye wastewater requires microbial growth conditions such as NPK, $\mathrm{pH}$, and culture temperature requirements. Take advantage of microbial degradation of dead cell nutrients to avoid the need for a training environment, while avoiding the impact of wastewater on the growth of living cells. Furthermore, dried microbial cell mass as an adsorbent and its activity of the enzyme is satisfactory for long-term storage. Furthermore, there are studies to report that the dried microbial cells can be effectively adsorbed by dye in the traditional sense of variety, such as indigo and so on.

The dye in the water-soluble system can be used as an industrial precursor material in the chemical process. Its characteristics are more readily soluble in aqueous solution. For example, using sulfuric acid to generate indigo carmine (Acid Blue 74, Fig. 1) it is a kind of common dye that may also be used as food additives of a microscopic tracer in biology, and as a tracer in analytical chemistry [10]. In this study, inactivated biomass of $H$. Insulare was used as a biological degradation of indigo carmine. The aim of this research was to develop effective adsorbents for dye-removal technology. Therefore, it is indispensable for researching the effect of respective<smiles>[NH2+]=S(=O)(c1ccc2c(c1)C(=O)C(=C1Nc3ccc(S(=O)(=O)O[NH3+])cc3C1=O)N2)[N+](=O)[O-]</smiles>

Fig. 1. Chemical structure of indigo carmine. operating parameters with degradation of dye, such as concentrations of dye initial $\mathrm{pH}$ and absorbent amount.

\section{Materials and Methods}

\section{Fungal Biomass Preparation}

The white rot fungus $H$. Insulare was cultured at $30^{\circ} \mathrm{C}$ on potato dextrose agar (S-PDA). After 1-2 weeks [11], the mycelium suspensions were preparatory and used for nurturing the inoculums. The mycelia suspension was transferred into $250 \mathrm{ml}$ flasks in $100 \mathrm{ml}$ potato dextrose agar (S-PDA). The proliferation medium consisted of $\mathrm{CaCl}_{2} \cdot 2 \mathrm{H}_{2} \mathrm{O}, 0.1 \mathrm{~g} ; \mathrm{FeSO}_{4} \cdot 7 \mathrm{H}_{2} \mathrm{O}, 0.40 \mathrm{~g} ; \mathrm{KH}_{2} \mathrm{PO}_{4}, 0.2 \mathrm{~g}$; $\mathrm{MgSO}_{4} \cdot 7 \mathrm{H}_{2} \mathrm{O}, 0.1 \mathrm{~g}$; $\left(\mathrm{NH}_{4}\right) \mathrm{H}_{2} \mathrm{PO}_{4}, 0.5 \mathrm{~g}$; glucose, $2.0 \mathrm{~g}$; and potato extract $100 \mathrm{ml}$. All of them were dissolved and mixed in distilled water. The fungal mycelium balls were formed in $2-5$ days under $30^{\circ} \mathrm{C}$ within $150 \mathrm{rpm}$. When the average diameter of mycelium ball diameters attain 3-5 $\mathrm{mm}$, it is time to gain pellets.

After centrifuging at 3,000 rpm for $15 \mathrm{mins}$ and rinsing in triplicate, the granules were dried at $30^{\circ} \mathrm{C}$ for $24 \mathrm{~h}$ and ground in a mortar to granularity of less than $100 \mu \mathrm{m}$ of dried powdered mycelium balls (called inactivated biomass). Inactivated biomass was used for dye degradation studies. The experiments were replicated in triplicate. The statistical analyses were performed in the SPSS 16.0.

\section{Analysis}

The concentration of the dye wastewater from the plant was $0.50 \mathrm{~g} / \mathrm{L}$. Accurately diluted dye stock solution as $0.1,0.2,0.3$, and $0.4 \mathrm{~g} / 1$, configured with different concentration gradients, got prepared test solution.

For setting different extensive inactivated biomasses with experimental design we transferred them to a

Table 1. Effect of time and agitation rate on the degradation (\%) of indigo carmine by dried powdered mycelium balls of $H$. Insulare.

\begin{tabular}{|c|c|c|c|}
\hline $\begin{array}{c}\text { Time } \\
\text { (minutes) }\end{array}$ & $\begin{array}{c}\text { Indigo carmine } \\
\text { removal } \\
(\%) \pm S d\end{array}$ & $\begin{array}{c}\text { Agitation rate } \\
(\mathrm{rpm})\end{array}$ & $\begin{array}{c}\text { Indio carmine } \\
\text { removal (\%) } \\
\text { Sd }\end{array}$ \\
\hline 30 & $88 \pm 0.57$ & Static & $92 \pm 0.57$ \\
\hline 60 & $93 \pm 0.57$ & 50 & $93 \pm 0.57$ \\
\hline 90 & $94 \pm 0.00$ & 100 & $94 \pm 1.00$ \\
\hline 120 & $94 \pm 0.57$ & 150 & $95 \pm 0.57$ \\
\hline 180 & $95 \pm 1.00$ & 200 & $93 \pm 2.51$ \\
\hline--- & --- & 250 & $95 \pm 2.08$ \\
\hline
\end{tabular}

SD: standard deviation; the results shown are averages of duplicate shake cultures and triplicate assays with SD within $10 \%$ of the mean; results are averages of three independent assays with SD within $10 \%$ of the mean. 
$100 \mathrm{ml}$ flask containing $2 \mathrm{mg} / \mathrm{l}$ of dye accommodated with distilled water. The impact of transfer was studies at different stirring rates of 10,40,80, 120, 160, and $200 \mathrm{rpm}$. The influences of the numerous dried powdered mycelium balls were investigated at different quantities, namely $0.1,0.2,0.3,0.4$, and $0.5 \mathrm{~g}$. In $20 \mathrm{ml}$ test tubes, the reaction of contact time was determined at 30, 60, 90, 120, and 180 minutes. For the sake of our study on the effect of $\mathrm{pH}$ on dye decomposition, the $\mathrm{pH}$ of the solutions was different from 2 to 8 , by adding $0.1 \mathrm{M} \mathrm{NaOH}$ and $0.1 \mathrm{M}$ $\mathrm{HCl}$ solutions. The effect of the original dye concentration on decomposition was studied between $150-500 \mathrm{mg} / \mathrm{L}$ at $30^{\circ} \mathrm{C}$. The concentration of residual dye was determined at their visible maxima for using absorbance values measured with a spectrophotometer comparing before and after the degrading treatment. All the experimental samples of the bio-sorption experimental system constructed three parallel samples. The same as the reference standard without adsorbent was the same tests and percentage decolonization was calculated as follows:

Decolorization $(\%)=\frac{(\text { Initial absorbance }- \text { Observed absorbance })}{\text { Initial absorbance }} \times 100$

\section{Results and Discussion}

\section{Effect of Adsorbent Amount on Decolorization}

The dye degradation of IC by dried powdered mycelium balls of $H$. Insulare was studied in changing the quantity of dried powdered mycelium balls $(0.1,0.2$, $0.3,0.4$, and $0.5 \mathrm{~g} / 20 \mathrm{ml}$ ) in the sample and repeating three times. For the original concentration of the dye the reaction temperature and time were $50 \mathrm{mg} / \mathrm{L}, 30^{\circ} \mathrm{C}$, 60 minutes, and 120 minutes. Unless otherwise indicated, the experiment was maintained without the variety of the $\mathrm{pH}$ of the dye solution. As expressed in Fig. 2, the percentage of discoloration was proportional to

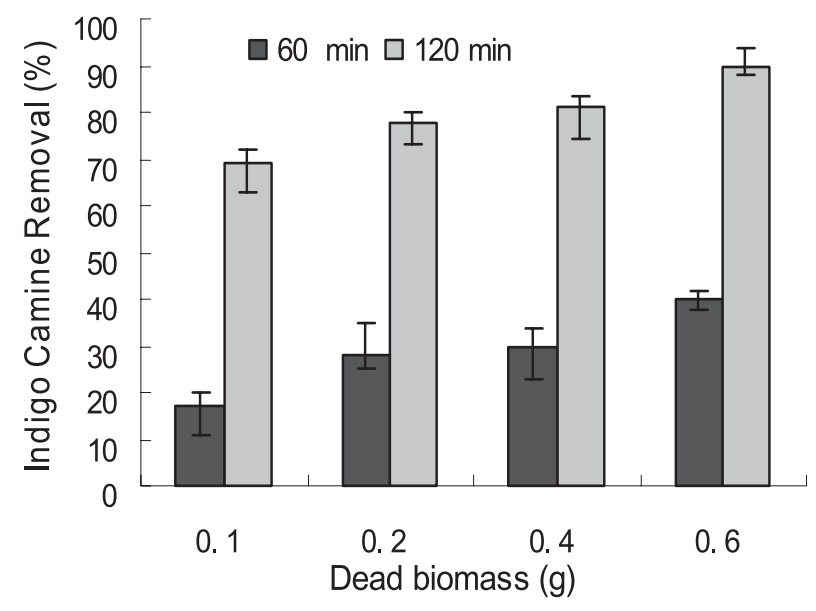

Fig. 2. Effect of dead biomass amount of H. Insulare on indigo carmine dye degradation. the adsorbent dose. In accordance with the above test, $0.2 \mathrm{~g} / 20 \mathrm{ml}$ of dried powdered mycelium balls were picked as the sorbent dose for further experiments.

The degradation effectiveness of gradient of amount of biomass was equivalent of $0.2 \mathrm{~g}$ and $0.5 \mathrm{~g}$, but more than $0.1 \mathrm{~g}$. It is more inclined to use smaller amounts of adsorbent in order to reduce operating costs on the scale of industrial applications. The plurality targets of adsorption position in dye degradation adsorbent dose increase can be attributed to increased adsorption surface area and availability. Discoloration of similar outcomes were reported for discoloration of astra-zone blue by inactivated biomass of H.Insulare [12]. The degradation mechanism to enhance the discoloration of malachite green was possible by raising the sorbent dosage of the agro product waste [13]. A similar study was in the news for degradation of quinoline blue and the analogous anionic dyes, separately [14].

\section{Effect of Initial $\mathrm{pH}$ on Decolorization}

The impact of original $\mathrm{pH}$ on the dye-waste degradation capacity of inactivated biomass H.Insulare was researched in the $\mathrm{pH}$ extent 3.0-8.0 to consider the influence of $\mathrm{pH}$ on discoloration capacity of inactivated biomass. The studies were implemented at $3 \mathrm{mg} / \mathrm{L}$ original dye waste concentration with $0.2 \mathrm{~g} 20 / \mathrm{mL}$ adsorbent mass of dried powdered mycelium balls 100 mesh at $30^{\circ} \mathrm{C}$ for 60 and 120 minutes and $150 \mathrm{rpm}$ (Fig. 3).

Variation $\mathrm{pH}$ on the degradation of dye wastewater adsorbent may be in two kinds of mechanisms. The electrostatic interaction between the carbon chain active with acidic dyes ionizable groups superimposed the reaction in chemicals among the adsorbents [15]. The interaction in dye molecules and the functional group biomass of the dead is inexplicable. Furthermore, there are oligo electronic interactions acting on site wastewater dye and dried inactivated biomass adsorbent on the surface. However, in this study the death of raw materials for dye

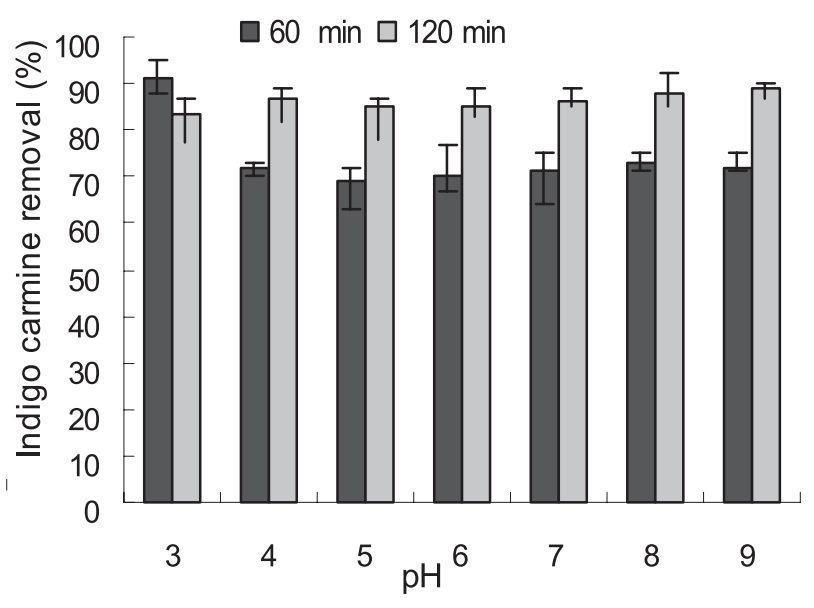

Fig. 3. Effect of $\mathrm{pH}$ on indigo carmine dye degradation. 
degradation capacity remained at 4.0-8.0, illustrating that dried biomass enzyme activity cannot be ignored. On the other hand, such action by a weak electrostatic attraction effect shows that mutual interaction strength cannot be neglected [16-17].

\section{Degradation of Indigo Carmine by Dried Powdered Mycelium Balls at Different Time Intervals}

The inactivated biomass of $H$. Insulare was tested for IC degradation capacity at different time intervals in this section of our research. To research the degradation reaction time on decolorization capacity of inactivated biomass, the experimental conditions are at $0.2 \mathrm{~g} / 20 \mathrm{ml}$ adsorbent mass $(100 \mathrm{mesh})$ at $30^{\circ} \mathrm{C}$ of the tests, which were conducted at $50 \mathrm{mg} / \mathrm{L}$ original concentration of dye, $\mathrm{pH} 2.0$, and $150 \mathrm{rpm}$. We observed that the color of dye degradation obviously happens within 60 min (Table 1). The color of dye degradation was higher than the start of absorption at the original period in $260 \mathrm{~min}$, and following this cycle the colorimetric of absorption in dyes did not undergo significant alterations.

\section{Effect of Stirring Degradation of Indigo Carmine Dried Powdered Mycelium Balls of $H$. Insulare}

To test the impact of stirring rate on the degradation of IC we used $0-250 \mathrm{rpm}$. To test the influence of the agitation rate of decolorization capacity of dried powdered mycelium balls in the experiment, the experimental conditions were at $0.2 \mathrm{~g} / 20 \mathrm{ml}$ adsorbent mass 100 mesh at $30^{\circ} \mathrm{C}$ for 60 minutes and $\mathrm{pH}$ of the experiments, which were implemented at $50 \mathrm{mg} / \mathrm{L}$ original dye concentration 2.0. The dried powdered mycelium balls high performance dye degradation was at the entire stirring rate (Table 1). As Table 1 shows, the agitation values of optimized operating conditions for decolorization were ranged from 150 to $250 \mathrm{rpm}$. As the stirring speed was reduced slightly, the degree of decolorization of dye activities was found to be lower. Maybe the reason is that the biomass particles agglomerate at lower agitation speeds [18]. Experimental data suggest that the discoloration of orange II attains $44 \%$ after $24 \mathrm{~h}$ blended incubation without agitation conditions and $95 \%$ with stirring conditions. This means

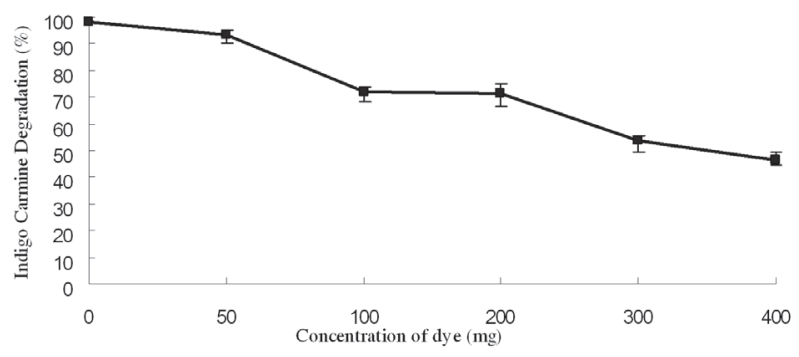

Fig. 4. Influence of original dye concentration $(\mathrm{mg} / \mathrm{L})$ on degradation of indigo carmine. that high decolorization yield offers many advantages in development of practical processes when in lower or static agitated conditions [19].

\section{Effect of Original Dye Concentration on Decolorization}

The influence of initial dye concentration of indigo carmine on decolorization reaction system biomass degradation processes was studied. Design of the experimental parameters is dry biomass dose was set to $0.2 \mathrm{~g} / 20 \mathrm{ml}$ solution at $30^{\circ} \mathrm{C}, \mathrm{pH} 2.0$, and fixed agitation 100-150 rpm for 60 minutes at different experimental initial concentrations of sample dye 50, 100, 200, 300, 400 , and $500 \mathrm{mg} / \mathrm{l}$. The degradation of dye by dried powdered mycelium balls of $H$. Insulare obviously relied on the initial dye concentration of the solution (Fig. 4). Dye degradation was reduced from $93 \%$ to $64 \%$ as increment concentration gradients from 100 to $1,500 \mathrm{mg} / 1$ indigo carmine. Under normal circumstances in the textile industry - due to the restrictions process - the threshold value of its wastewater discharge is not more than $500 \mathrm{mg} / \mathrm{l}$, and conventional dye concentration is about $10-50 \mathrm{mg} / \mathrm{l}$. As a result, it is fairly significant to take precautions against environmental pollution.

\section{Conclusions}

During the last decade, research has focused on the development of new degradation technologies that result in complete decomposition of dye molecules. In the present study, dried powdered mycelium balls of $H$. Insulare were applied successfully for the sorption of indigo carmine. The operating conditions may lead to a negative effect on discoloration with living cells regarding concentration of dye, reaction system $\mathrm{pH}$, and temperature. However, it has many advantages compared with live biomass inactivated biomass. Inactivated biomass may be stored or prolonged in application and the operation is not difficult and its regeneration is not complicated. Inactivated biomass may be produced with industrial and agricultural by-products. Therefore, it can be used as inexpensive and effective biosorbent.

By inactivated biomass of $H$. Insulare with the experimental conditions at $30^{\circ} \mathrm{C}$ and $\mathrm{pH} 2.0$ of the experiments whose exploration of was at fixed a sorbent dose $(0.2 \mathrm{~g} / 20 \mathrm{ml})$ in the experimental system of solution. The results obtained for the principle as it relates to dye degradation can be regarded as a prophase procedure for the representativeness of the experimental behavior and for developing technological design.

\section{Acknowledgements}

This work was supported by the Natural Science Foundation of Heilongjiang Province, China (Nos. C201452). 


\section{References}

1. PIRKANNIEMI K., SILLANPÄÄ M. Heterogeneous water phase catalysis as an environmental application: a review [J]. Chemosphere, 48 (10), 1047, 2002.

2. GUTIERREZ-SEGURA E., SOLACHE-RÍOS M., COLÍNCRUZ A. Sorption of indigo carmine by a Fe-zeolitic tuff and carbonaceous material from pyrolyzed sewage sludge [J]. Journal of Hazardous Materials, 170 (2), 1227, 2009.

3. RANADE V.V., BHANDARI V.M. Industrial Wastewater Treatment, Recycling, and Reuse: An Overview [J]. Industrial Wastewater Treatment, Recycling and Reuse, 1, 2014.

4. FU Y., VIRARAGHAVAN T. Fungal decolorization of dye wastewaters: a review [J]. Bioresource Technology, 79 (3), 251, 2001.

5. RAFATULlAH M., SULAIMAN O., HASHIM R., AHMAD A. Adsorption of methylene blue on low-cost adsorbents: a review [J]. Journal of Hazardous Materials, 177 (1), 70, 2010.

6. MAURYA N.S., MITTAL A.K., CORNEL P., ROTHER E. Biosorption of dyes using dead macro fungi: effect of dye structure, ionic strength and $\mathrm{pH}[\mathrm{J}]$. Bioresource Technology, 97 (3), 512, 2006.

7. KANNAN N., SUNDARAM M.M. Kinetics and mechanism of removal of methylene blue by adsorption on various carbons-a comparative study [J]. Dyes and Pigments, 51 (1), $25,2001$.

8. AKSU Z. Application of biosorption for the removal of organic pollutants: a review[J]. Process Biochemistry, 40 (3), 997, 2005.

9. GADD G.M. Biosorption: critical review of scientific rationale, environmental importance and significance for pollution treatment [J]. Journal of Chemical Technology and Biotechnology, 84 (1), 13, 2009.

10. AMMAR S., ABDELHEDI R., FLOX C., ARIAS C., BRILLAS E. Electrochemical degradation of the dye indigo carmine at boron-doped diamond anode for wastewaters remediation[J]. Environmental Chemistry Letters, 4 (4), 229, 2006.

11. ROSIK-DULEWSKA C., MICHALSKI R. Thirty-seven years of archives of environmental protection [J]. Archives of Environmental Protection, 38 (3), 3, 2012.

12. RAO N., CANNELLA B., CROSSETT L.S., YATESJR A.J., McGough R. A preoperative discoloration protocol for Staphylococcus aureus prevents orthopaedic infections [J]. Clinical Orthopaedics and Related Research, 466 (6), 1343, 2008.

13. YAGUB M.T., SEN T.K., AFROZE S., ANG H.M. Dye and its removal from aqueous solution by adsorption: a review [J]. Advances on Colloid and Interface Science, 209, 172, 2014.

14. CHEN C., ZHAO W., LI J., ZHAO J. Formation and identification of intermediates in the visible-light-assisted photodegradation of sulforhodamine-B dye in aqueous $\mathrm{TiO}_{2}$ dispersion [J]. Environmental Science \& Technology, 36 (16), 3604, 2002.

15. SHOUMAN M.A., FATHY N.A., EL-KHOULY S.M., ATTIA A.A. Equilibrium, kinetic and thermodynamic studies of the adsorption of acidic dye onto bagasse fly ash[J]. Carbon Letters, 12 (3), 143, 2011.

16. KAHRAMAN S., KURU F., DOGAN D., YESILADA O. Removal of indigo carmine from an aqueous solution by fungus Pleurotus Ostreatus [J]. Archives of Environmental Protection, 38 (3), 51, 2012.

17. CHOWDHURY M., ISLAM R. Biosorption of arsenic by anaerobic biomass [D]. Concordia University, 2007.

18. JEFFERY D.W, WILKINSON K.L. 2.1 Evaluation of Wine [J]. The Oxford Handbook of Food Fermentations, 7426 (67607), 54, 2014.

19. KNAPP J.S. Use of wood-rotting fungi for the discoloration of dyes and industrial [J]. Fungi in Bioremediation, 23, 242, 2001. 